\title{
Defect Index of Timberwork in House, Korea
}

\author{
Junmo Park ${ }^{1}$ [D and Deokseok Seo ${ }^{2, *}$ \\ 1 Laboratory of Construction Technology, Kyungsan Engineering Co. Ltd., Seocho-gu, Seoul 06646, Korea; \\ adviser.cm@gmail.com \\ 2 School of Architecture, Halla University, Wonju-si 26404, Korea \\ * Correspondence: seodk@halla.com; Tel.: +82-10-2289-9946
}

Citation: Park, J.; Seo, D. Defect Index of Timberwork in House, Korea. Forests 2021, 12, 896. https://doi.org/10.3390/ f12070896

Academic Editors: Miroslav Premrov and Vesna Žegarac Leskovar

Received: 28 May 2021

Accepted: 6 July 2021

Published: 8 July 2021

Publisher's Note: MDPI stays neutral with regard to jurisdictional claims in published maps and institutional affiliations.

Copyright: (c) 2021 by the authors. Licensee MDPI, Basel, Switzerland. This article is an open access article distributed under the terms and conditions of the Creative Commons Attribution (CC BY) license (https:// creativecommons.org/licenses/by/ $4.0 /)$.

\begin{abstract}
Wood is a material that is familiar to humans and environment-friendly, and it is used widely as a building material. However, as the dispute over housing defects have increased in Korea, various defects have occurred in timberwork and have become disputes. Notwithstanding, efforts to analyze defects in timberwork systematically to reasonably solve the problem are lacking. In this study, defects in timberwork from housing complexes in Korea were standardized, and critical defects were selected to suggest a method as a management standard. The standard for defects includes time, types of facility work, location and subject, and defect phenomenon. The defect time is categorized into before handover and after handover, whereas facility work is divided into woodwork, door and window work, finishing work, and miscellaneous work. Location and subject are categorized into 13 areas, such as ceiling, floor, and door, and phenomena concerned are of 14 types, including faults and no installation. Therefore, the standardized defect items according to such criteria are classified into a total of 63 types. Ten defect items, whose numbers of defect occurrences per defect and defect repair cost ratio above the average, were selected, including discoloration and breakage of the wooden floor. The repair cost ratio of these defect items accounted for $85.62 \%$ of the total repair costs. On the contrary, the repair cost for the defects from the timber work outlined in the Construction Appraisal Practice, a representative defect standard in Korea, was $54.54 \%$ of the total. Meanwhile, according to the Defect Judgment Standard, the defect repair cost attributed $45.54 \%$ of the total. Therefore, since the 10 defect items proposed in this study can explain the defects in the timberwork compared with other standards, it would be reasonable to designate these 10 defect items as essential defects.
\end{abstract}

Keywords: defect index; timberwork; number of defect occurrence per defect; repair cost ratio

\section{Introduction}

Men have coexisted with forests and trees, and we have been using them at no cost till industrialization [1]. Human life has continued around forests and trees all over the world and has survived with shelter, food, building materials, and fuel [2]. Humanity on the Korean Peninsula, where Korea is located, has also been provided with various resources necessary for survival from the forests [3]. Notably, wood obtained from the forest has been widely used because it is easy to obtain and convenient for processing among construction materials [4]. Moreover, wood can be repaired and replaced even if it has some damaged parts, and it is easy to move to another place because it can be disassembled and reassembled [5].

Though wood is vulnerable to fire [6,7], requires moisture control [8], and may be damaged by harmful insects such as termites $[9,10]$, technologies and products to prevent these incidents have been continuously developed and distributed [11,12], and if they are managed well without man-made accidents, it can be used for centuries or more. In addition, the extraction and process of timber takes less energy than materials such as steel, but it is also recycled to the original ecosystem by naturally decomposing even if it is disposed after use, giving a small load to the environment [13,14]. In addition, if the 
wood is used with a partially processed level of its natural condition, it emits lesser organic chemicals that are harmful to the human body [15]. With such merits, using wood is mainly recognized as eco-friendly and helpful to humans.

The history of wooden house construction in Korea is also long, and there are many wooden structures [16]. Government offices [17], temples [18], Confucian schools [19], Confucian academies [20], and houses [21], which are traditional structures constructed before industrialization, have been built with their pillars, beams, roof trusses, floors, finishing materials, windows, and doors. However, wood from forests has long been used as fuel and construction material, globally excessive deforestation has been committed, and forests have sometimes perished due to natural disasters like forest fire [22,23]. In Korea, mountain and forest resources were excessively used through an economic invasion that began in the 1910s, which made it difficult to obtain valuable timber [24,25], and many structures and houses were destroyed and demolished by the Korean War in 1950 [26,27]. Beginning in the 1960s and until the 1980s, urbanization rapidly progressed with industry development $[28,29]$. From the 1990s, when urbanization reached its peak, more than $80 \%$ of the entire population [30] and more than $90 \%$ lived in cities in the 2010s [31]. Accordingly, the housing type was converted to a large-scale apartment complex with various amenities and energy supply facilities [32,33]. Despite the ample supply of houses in the industrialization era, demand for new housing is still rising due to the residents desire to improve the quality of housing and economic development. Therefore, each country's government supplies vast quantities of new housing annually [34], as well as private sectors also steadily construct houses [35].

Many people are involved in the construction of houses and works are extensive and complicated [36]. Therefore, claims in relation to construction cost, construction period, and house quality often arise [37]. In general, as construction increases, the case of dispute likewise does [38], and this dispute is categorized into design defects, incomplete construction, materials defect, and vague construct terms [39]. In recent days, excessive housing supply plan has caused a shortage of skilled manpower, materials, and equipment [40,41], while complaints, such as defects or incompleteness of houses, have also increased [42]. In Korea, representative defects related to woodworking include floor defects and damages, opening and closing faults of furniture and windows, and ceiling molding defects, in which functions or aesthetic aspects are the main concerns [43].

Lawsuits related to construction are complicated with technical issues, so it is challenging to make judges or jury members, who are not professional engineers, accurately recognize the problem. Therefore, professional consultants of engineers are hired to diagnose problems related to the dispute, and they submit reports of the defect repair methods, cost, or duration of repair [44,45]. Not only this, insurance or warranty systems are arranged in preparation for the occurrence of defects in the structures, but a reasonable approach to payoff good insurance premium or deposit is required according to the extent of damage [46,47]. Nonetheless, related research itself is lacking [48], making the systematic approach difficult.

Since the 2000s, lawsuits have been a social problem in Korea due to their increasing number concerning housing quality, so various studies and standards have been proposed. However, most of the studies dealt with overall house matters, and studies focusing on the quality or defects of houses are also insufficient.

There is the Building Act, Housing Act, Act on Ownership and Management of Aggregate Buildings, Construction Business Act, and Construction Technology Promotion Law regarding house defects. However, these laws stipulate only the defect warranty liability period and defect repairing deposit. According to exemplified defect phenomena, the only law that specifies some of the defect cases is the Housing Act, but the detailed classification is not provided [49,50]. For example, as defects related to woodworking, there are cracks, deflection, distortion, breakages, and collapse, but facilities and specified subjected parts are not defined. 
Construction Appraisal Practice is a standard drawn up by the Society for Construction Lawsuit, Seoul Central District Court, and is a standardized version of the appraisers who support judgment benches in the construction lawsuit. In the Construction Appraisal Practice, house defects are categorized into cracks, finishing, waterproofing, landscape, and facilities, and defect status is judged for each matter [51,52]. The defect types in woodworking defined in the Construction Appraisal Practice are as follows.

- Gap difference in wooden ceiling frames

- No installation of wooden floor under kitchen

- Mismatch of wooden floor molding

- No installation of wooden door edge finishing

- Poor opening and closing of wooden windows

- Default in installation, poor opening and closing, and sheet falling in the rooms and kitchen furniture

The defect determination in multi-family housing, methods of investigation, and standards for calculating repair costs are the standards utilized by the Dispute Mediation Committee, Ministry of Land, Infrastructure, and Transport [53,54] for housing defect dispute settlement. Defect types in woodwork suggested by this standard are as follows.

- No installation of wooden floor in the lower parts of the kitchen

- No installation of wooden door edge finishing

- Poor opening and closing of wooden windows

However, the defect types prescribed in the relevant laws in Korea are abstract in nature, and the defect types suggested by the relevant standards do not represent the total defect types [52]. Significantly, nothing was revealed about the bases or methods of how these defect types were chosen. From a general point of view, there can be cases of frequent defect occurrence, considerable damage by defect, and the high cost required to repair the defects. Nonetheless, the above two standards propose only confirmed defect items and types, and these cannot be known as of now since the methodologies are not specified.

Therefore, it is necessary to perform studies about what kinds of defects practically occur in the woodworks of the houses and what is to be managed with a focus in case frequent defects occur or when the defect occurs and the repair cost is high. In this connection, some studies have been conducted for electric work [52], reinforced concrete work [54], facility construction [55], and landscaping [56].

Regarding woodworking as a research trend, Chong and Low suggested some defects occurred from the wooden ceiling and walls [57], but they did not go into the details. Studies by Vásquez-Hernández and Botero categorized the case and location of defects and systematically analyzed defect occurrence by causes and locations [58]. However, they could not specifically suggest defect types for the woodwork. Delgado et al.'s study presented a method of diagnosing defects in the wooden floor in detail according to the cause [59]. Mousavi et al. proposed an inspection method of the holes' defects in woodworking [60]. Sassu and Falco studied the problems of collapsing the wooden floor and roof due to decreases in shearing force [61]. Walsh-Korb and Avérous systemically organized defect status and methods by analyzing the cause of defect, processing, and surface of wood [62], but they overlooked the defect in complete woodworking. Du et al. proposed a method to inspect internal defects from outside of hardwood using sensors [63]. Kamal et al. and Shi et al. established a database for the defect conditions such as splitting the wood surface and knots, and they classified defect types through machine learning techniques $[64,65]$. Notwithstanding, this research could help find defects in hardwood or processed wood, but it was not sufficient to find defect types in detail or improve such defects.

As reviewed above, related standards and kinds of literature could not systematically propose what kind of problem occurred from which subjects. Furthermore, it was also confirmed that the analysis subjects were not sufficient, and they failed to propose quantitative criteria or a standard for comparison. Therefore, this study aims to categorize the objects 
and locations of defects for each detailed facility work where woodworks are included by focusing on houses, and defect types of woodwork are standardized by specifying the defect phenomena. In addition, critical defects are designated in consideration of frequencies of defects and occupancies in total defect repairing cost to propose a standard necessary for defect management.

\section{Materials and Methods}

\subsection{Target Object}

The woodwork subject for analysis in this study refers to general construction works using wood to build the house itself in Korea. In the Korean Housing Act, construction is broadly categorized into 18 types of facility works according to each location of the house and work types, and then each work is subdivided into 80 types [66]. Among these work types, woodwork is specified into two types: 1 . structure and base material work and 2 . wood for fixture [43]. However, construction using wood as a material extends to windows and doors, wooden fixtures among finishing, and interior furniture for kitchen systems among miscellaneous works. Therefore, in this study, timber construction encompasses detailed constructions that use wood as the primary material in house construction. However, there is no standardized design for auxiliary facilities installed outside of the house. There is a significant difference in each case and these were excluded in this study. The previous study focused on the defect at the time of construction of the timber itself or the houses, while this study focused on the defects generated or confirmed during use after the handover of the houses. In addition, preceding studies dealt with some timbers, while overall timbers used for house construction are dealt with in this study.

In addition, the most common and similarly designed and constructed multi-family houses among Korean houses were chosen as study subjects. Detached houses are designed in various ways to depend on the need of the owners and the designer's intention, so the scope is too extensive, making it challenging to standardize, along with tiny detached houses newly constructed. Therefore, sufficient case data cannot be collected. For this study, defect types should be standardized first, but detached houses are difficult to study for the above reasons. On the other hand, multi-family houses are being constructed according to the standardized house design $[67,68]$, and great differences do not exist except for some specialized items. Therefore, the comparison of defects from multi-family houses rather than detached houses would avoid big deviations and produce statistically significant results.

Meanwhile, defects are sometimes categorized based on the time of defect occurrence. For example, according to Article 46 of the Housing Act and Article 5 of the Act on Ownership and Management of Aggregate Buildings, there is an occurring defect after handover, which is subject to defect repairing guarantee, and the term of defect warranty liability is set over a period of $1-10$ years $[69,70]$. On the other hand, there is an occurring defect before handover, protected by Article 671 (1) of the Civil Act and Article 5 of the Act on Ownership and Management of Aggregate Buildings. According to the applicable laws for these defects, the exclusion period is applicable for 5 years or 10 years [70,71]. Therefore, in this study, defect types were standardized by considering the defect occurrence period following these laws.

There is a problem of unity in terms of terminology, subjects, and phenomena of defects in the standards and studies about timberwork. Therefore, defect appraisal reports, which are case studies, were collected and analyzed in this study. These defect appraisal reports were prepared and submitted by the appraisers whom the courts appointed for defect lawsuits of the houses in Korea [45]. Courts then decided if the defects could be accepted considering evidence and circumstance among the defect phenomena in the appraisal report and finally announced the defect acknowledgment status and repair amount in the decision [72].

However, the appraisal report is vast enough to amount to hundreds or thousands of pages since it contains investigations on defects in timberwork and housing construction in 
general. Furthermore, there is a limit to data not being disclosed to the public and cannot be accessed except by the parties to the lawsuit. In addition, although the decision is less than a dozen pages in length, it must be applied separately and is not to be unconditionally disclosed. Due to such limitations, there was difficulty in obtaining the case data. Furthermore, though the defect repairing cost is calculated in the summary table provided in the defect appraisal report and the court decision, it cannot distinguish whether the cost falls under defect repairing of the timberwork, and detail should be checked. In this study, one could read the relevant data with the help of the experts of construction-related disputes and set the index of common defects and weightage calculation based on the obtained data.

Furthermore, the defect items described in the defect appraisal report and the decision were prepared by the divided owner, administration office, or outsourcing consulting agencies of the houses, not by the experts like appraisers and executives-in-charge who investigate defects. Therefore, since non-experts write defective items, the terms can be different even though they refer to the same object, and they are sometimes written in by borrowed foreign words rather than standard Korean words. In short, defect items in the defect lawsuit are not standardized. Due to this reason, a certain number of defect items are proposed in the Construction Appraisal Practice [51] and Defect Judgment Standard [53], as in the previous studies. However, these are not mandatory, so it is not obligatory to follow them. In addition, the number of defect items proposed by them is far too small compared to the defect items that occurred for real. Therefore, there were many insufficient points to explain the defects though those have been confirmed through this study.

Principally, the best is to prevent defects in advance because defects do not benefit either the divided owner or project owner but inevitably occur due to various reasons and environmental factors. Should there be a standard defect index, defect occurrence can be figured out in advance; thus, it can prevent the problem by confirming the defect during designing or construction. In addition, it could help in finding the status by checking the defects that occurred after the handover of the houses. For the divided owners, they will know if there is a defect occurring in their houses by utilizing the standard defect index. Since it can prevent further damage if the defect is found early and prevention measures and repair are performed through a standard defect index, this can benefit both the divided owner and project owner. Meanwhile, in the defect lawsuit, many cases where defects are claimed by a divided owner who is not an expert are challenging to clarify. For the appraiser, the standardized defect index is helpful since it makes communication smooth with the divided owner and investigation can be executed promptly.

In order to set a standard defect index more objectively, the relative importance of the defects was evaluated in this study. As evaluation parameters of relative criticality, the number of cases and the defect cost ratio are suggested. If defects occur at a similar level across all defect items or if the repair cost does not differ significantly, this corresponds to the Long Tail rule regarding quality and business management $[73,74]$. In such cases, efforts and expenses must be evenly distributed. However, as can be seen from the results in Section 3 of this study, if defects occur in concentration in a specific small number of defect cases, or defect repair is heavy, it falls under Pareto's law, which is the opposite case of Long Tail theory at quality and management aspect $[75,76]$. In such a case, it would be reasonable to focus on specific defect items. Due to this reason, in this study, many defect cases and defect repairing cost ratios per defect index were calculated based on the case study. Those indices with a number of defect occurrences and defect repairing cost ratios higher than average were selected and proposed as prime indexes. Since the number of defect cases and the defect repairing cost ratio per defect index can be an index of quality control for design and construction from a practical perspective, it is well worth it. It gives the advantage of understanding the overall status at management point of view and makes relative evaluation possible.

Lastly, the occupancies of the defect repairing cost for the key defect items and defects proposed in the initial studies were compared for the cases of Construction Appraisal Practice and the Defect Judgment Standard to the total defect repairing cost. Therefore, 
whether the standard defect index of timberwork follows the Long Tail theory of Pareto's rule, will determine if the quality and management strategy will be employed differently.

\subsection{Process}

This study was executed as in the sequence below, and the detail of each sequence is described further in Section 2.3.

1. Appraisal Reports and decisions of housing defect lawsuits were collected as case study materials.

2. Standard defect index was established based on the case study.

3. The number of case and defect repair cost ratios per defect index were calculated.

4. A separate prime index was established with only defect indices higher than average.

5. The defect repairing cost ratios between the prime index and the index suggested in the previous study were compared.

\subsection{Method}

\subsubsection{Case Collection}

The appraisal report and the decision for the housing complexes, for which defect lawsuits in Korea were provided by the construction dispute experts, as well as defect items related to the timberwork were extracted from these data. The defect items that were specified in the summary of the appraisal reports and the decisions were chosen. Most of the five classification factors, such as defect occurring period, location, category of facility construction, objects, and phenomena proposed as categorization factors for the standard defect index in Section 2.3.2, were primarily classified in the appraisal report. Nonetheless, some cases were not classified depending on the cases. In addition, some cases were wrongly classified, and these were amended through standardization.

\subsubsection{Index Standardization of Defect Type}

Since there is no uniformity in the defect terms, subjects, and phenomena proposed by standards and research related to the woodworking, case data were collected and analyzed to standardize defect types. However, since the defect items indicated in the appraisal report and judgment are not standardized, this study performed standardization while organizing case data. As described above, even though the defect is the same, it may be mistaken as a different defect due to differences in expression method and used terminology. Therefore, standardization was performed based on the five classification factors: defect occurrence period, category of facility construction, defect occurrence location, object, and phenomenon.

Accordingly, standardization proceeded in the following sequence.

1. Extraction of defect items from the appraisal report and judgment decision by each case.

2. Grouping the defect items of Step 1 among similar items.

3. Categorization of defect occurrence timing into occurring defect before handover and occurring defect after handover.

4. For Step 3, categorization of facility works (wooden work, window work, finishing, and miscellaneous works) related to woodworking in the Housing Act.

5. For Step 4, categorization according to location and area where the defect occurs.

6. Categorization according to the subject of defect for Step 5 (categorized into being more specific than Step 5, which can be omitted)

7. Categorization by a phenomenon in questions for Steps 5 and 6.

The defect index standardized through the above process is composed as in Table 1.

Table 1. Total defect index list of cases.

\begin{tabular}{llllll}
\hline Code & Occurring Time & Work & Location & Object & Phenomena \\
\hline
\end{tabular}




\subsubsection{Comparison Factor Suggestion}

As reviews show above, there is no exceptional alternative due to lack of research on defect category, and it is challenging to set the standard and criteria because actual cases or experimental data are also lacking. Accordingly, in this study, numbers of defect occurrence and defect repairing cost ratio were selected as criteria to compare the severity of defects and fitness between critical standards.

The number of defect occurrence cases was counted as one (1) when a defect item was confirmed in one case. Since 100 cases were studied in this study, the number of defect occurrences became a minimum of 0 to a maximum of 100 . If the defect occurrence case is more, the defect item can be regarded as a defect that appears frequently.

The defect repair cost ratio refers to the defective item's defect repair cost out of the total repair cost after accounting for the defect repair cost for each defect item. The higher the defect repair cost ratio, the greater the damage caused by the defect. Defect repair costs were based on the amount finally recognized in the judgment for each case. Meanwhile, since the time of repair cost calculation per case was different, it was necessary to rectify the difference. With the base date as the end of 2020, the repairing cost was converted using the present value method reflecting the $0.965 \%$ yield to maturity of government bonds announced by the Central Bank of Korea [77].

\subsubsection{Prime Index Draw and Comparison}

By comparing the number of defect occurrence cases and defect repairing cost ratio, the defect items were confirmed as the two above factors were more than average selected as key defect items. The ratio of these key defect items to the defect repair cost for the entire timber construction was compared with the defect repair cost ratio of the items suggested in the prior studies.

\section{Results}

\subsection{Case Outline}

The collected cases of defect-related lawsuits consisted of a total of 100 complexes that were built in 1-10 years. The most minor complex consisted of 96 households, and the most extensive complex consisted of 3129 households, and both were included in a total of 81,431 households. The defects of woodworks identified before standardization included 610 cases, and the repair cost was KRW 4.26 billion, which was equivalent to USD 3.90 million when applying the exchange rate at the end of December 2020.

Korea can be divided into five areas according to the distribution of rivers and mountains, as shown in Figure 1. The metropolitan area is located in the northwest region and includes Incheon and Gyeonggi-do, with Seoul's capital. Gangwon Province is located in the rugged mountains in the northeast. The Hoseo area is a topographical terrain where mountain ranges pass up and down, and hilly areas exist between them and include Chungcheongbuk-do, Chungcheongnam-do, Daejeon, and Sejong. Honam area has mountain ranges in the northeast part, but unlike other areas, it is made up of vast plains and consists of Jeollabuk-do, Jeollanam-do, and Gwangju. Finally, the Yeongnam area is located in the southeastern mountainous region and includes Gyeongsangbukdo, Gyeongsangnam-do, Daegu, Ulsan, and Busan in the inland basin and some plains downstream of the river.

More than half of the number of housing complexes and owners of the study subject are concentrated in the metropolitan area. Since half of Korea's population is concentrated in the metropolitan area, the demand for housing and construction volume is high in the metropolitan area and, accordingly, many defect lawsuits are filed. Next comes Yeongnam and Hoseo areas, which are the most populous after the metropolitan area. Finally, Honam and Gangwon are regions with a declining population, and the number of cases is also small. 


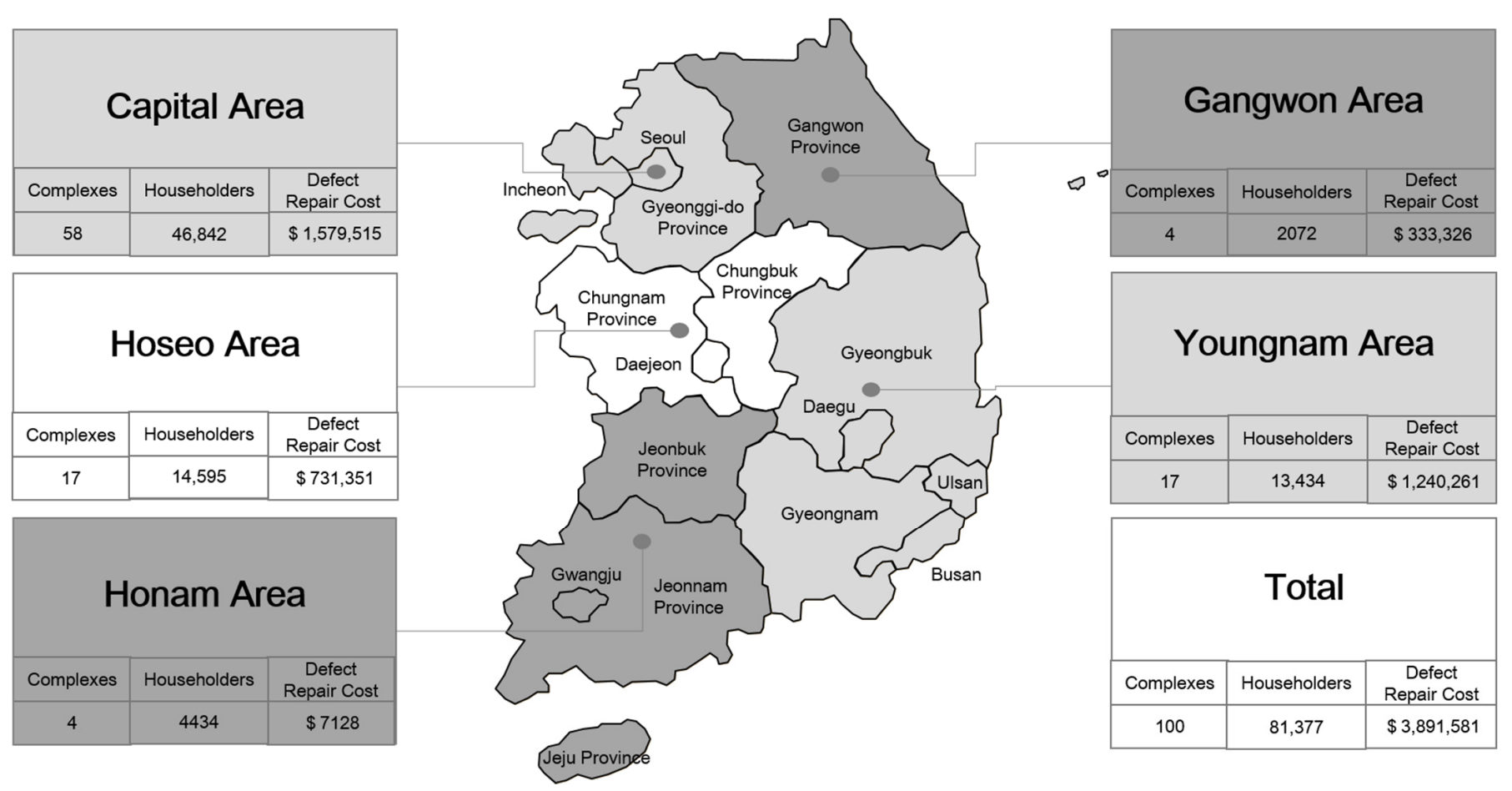

Figure 1. Case distribution.

\subsection{Defect Index A}

Table 2 shows the standardized defects items of woodworks drawn from the case study, and these were marked as Index A after adding code A to identify defect items in other standards. A total of 63 defect items were drawn, and there were 23 cases from A1 to A3 that occurred before handover. While the occurring defect after handover was 40 cases from A24 to A63, there were more types of defects that occurred after construction.

As defects in the facility occurred, woodwork defects consisted of 7 types from A1 to A4 and A24 to A26, whereas door and window faults consisted of 22 types from A5 to A12 and A27 to A40. While finishing works, related defects were 24 types from A13 to A21 and A41 to A55. Finally, the defects in the miscellaneous works consisted of 10 types from A56 to A63. Therefore, defects were high in the finishing work and window work.

As far as location and object of defects were concerned, 13 in the ceiling, 3 in the floor, 1 in the wall area, 2 in the skirting board, 2 in the finishing and others, 6 in the doorframe, 7 in the doors, 4 in the windows, 3 in the accessories of the window, 2 in the windows and others, 10 in the interior furniture, 9 in the kitchen furniture, and 1 in the miscellaneous work were classified. The ceiling, interior furniture, kitchen furniture, doors, and door frames had the most defects in location and object.

By looking at the defect phenomena, it was classified into 21 defects, 12 non-installations, 6 mismatches with drawings, 6 dropouts, 3 poor openings and closings, 3 incomplete fixations, 3 breakages, 2 interferences, and 2 cleavages. In addition, different sizes, excessive gaps, mismatches with industrial standard, decays, discolorations, and breakages were identified as one type each. Representative defects were defects, no installations, mismatches with drawings, and dropouts. 
Table 2. Total defect index list of cases.

\begin{tabular}{|c|c|c|c|c|c|}
\hline Code & $\begin{array}{l}\text { Occurring } \\
\text { Time }\end{array}$ & Work & Location & Object & Phenomena \\
\hline A1 & \multirow{23}{*}{$\begin{array}{l}\text { occurring } \\
\text { defect } \\
\text { before } \\
\text { handover }\end{array}$} & \multirow{4}{*}{$\begin{array}{l}\text { wooden } \\
\text { structure } \\
\text { work }\end{array}$} & \multirow{4}{*}{ ceiling } & hanger & non-installation \\
\hline A2 & & & & frame & unmatched size \\
\hline $\mathrm{A} 3$ & & & & height & mismatch withdrawing \\
\hline A4 & & & & molding & non-installation \\
\hline A5 & & \multirow{8}{*}{$\begin{array}{l}\text { window } \\
\text { and } \\
\text { door work }\end{array}$} & \multirow{2}{*}{ door frame } & & excessive gap \\
\hline A6 & & & & finishing & non-installation \\
\hline A7 & & & \multirow{2}{*}{ door } & anti-rotting of end pieces & non-installation \\
\hline A8 & & & & opening direction & overlap \\
\hline A9 & & & window and door & & non-installation \\
\hline A10 & & & attachment & & non-installation \\
\hline A11 & & & window and door & & mismatch withdrawing \\
\hline A12 & & & others & caulking & non-installation \\
\hline A13 & & \multirow{9}{*}{$\begin{array}{l}\text { finishing } \\
\text { work }\end{array}$} & \multirow{2}{*}{ ceiling } & molding & mismatch withdrawing \\
\hline A14 & & & & finishing & mismatch withdrawing \\
\hline A15 & & & skirting board & & mismatch withdrawing \\
\hline A16 & & & Tor don flor & & non-installation \\
\hline A17 & & & wooden floor & under kitchen system & non-installation \\
\hline A18 & & & \multirow{4}{*}{$\begin{array}{l}\text { interior } \\
\text { furniture }\end{array}$} & \multirow{2}{*}{ attachment } & non-installation \\
\hline A19 & & & & & mismatch withdrawing \\
\hline A20 & & & & & mismatch with industrial standard \\
\hline A21 & & & & & non-installation \\
\hline A22 & & \multirow{2}{*}{ miscellaneous work } & \multirow{2}{*}{$\begin{array}{l}\text { kitchen } \\
\text { system }\end{array}$} & opening direction & overlap \\
\hline A23 & & & & attachment & non-installation \\
\hline A24 & \multirow{17}{*}{$\begin{array}{l}\text { occurring } \\
\text { defect } \\
\text { after } \\
\text { handover }\end{array}$} & \multirow{3}{*}{$\begin{array}{l}\text { wooden } \\
\text { structure } \\
\text { work }\end{array}$} & \multirow{3}{*}{ ceiling } & structural part & malfunction \\
\hline A25 & & & & molding & malfunction \\
\hline A26 & & & & & malfunction \\
\hline A27 & & \multirow{14}{*}{$\begin{array}{l}\text { window } \\
\text { and } \\
\text { door work }\end{array}$} & \multirow{2}{*}{$\begin{array}{l}\text { window } \\
\text { and door }\end{array}$} & & opening and closing fault \\
\hline A28 & & & & finishing & drop out \\
\hline A29 & & & \multirow{4}{*}{ door frame } & finishing & malfunction \\
\hline A30 & & & & & flexure \\
\hline A31 & & & & & fault of attachment \\
\hline A32 & & & & & breakage \\
\hline A33 & & & \multirow{5}{*}{ door } & & malfunction \\
\hline A 34 & & & & & flexure \\
\hline A35 & & & & cover sheet & drop out \\
\hline A36 & & & & bottom and end header & rotting \\
\hline A37 & & & & & drop out \\
\hline A38 & & & \multirow{2}{*}{ attachment } & door lock & malfunction \\
\hline A39 & & & & door hinge & malfunction \\
\hline $\mathrm{A} 40$ & & & others & caulking & malfunction \\
\hline
\end{tabular}


Table 2. Cont.

\begin{tabular}{|c|c|c|c|c|c|}
\hline Code & $\begin{array}{l}\text { Occurring } \\
\text { Time }\end{array}$ & Work & Location & Object & Phenomena \\
\hline A41 & & \multirow{15}{*}{ finishing work } & floor & wooden floor & discoloration and breakage \\
\hline A42 & & & wall & wooden wall & malfunction \\
\hline A43 & & & $\begin{array}{l}\text { skirting } \\
\text { board }\end{array}$ & wooden skirting board & malfunction \\
\hline A44 & & & \multirow{4}{*}{ ceiling } & wooden ceiling & malfunction \\
\hline A45 & & & & wooden lighting box & malfunction \\
\hline A46 & & & & wooden curtain box & malfunction \\
\hline A47 & & & & well type wooden ceiling & malfunction \\
\hline A48 & & & \multirow{2}{*}{ others } & caulking & malfunction \\
\hline A49 & & & & cover sheet & drop out \\
\hline A50 & & & \multirow{6}{*}{$\begin{array}{l}\text { interior } \\
\text { furniture }\end{array}$} & & fault of attachment \\
\hline A51 & & & & & breakage \\
\hline A52 & & & & & opening and closing fault \\
\hline A53 & & & & door hinge & malfunction \\
\hline A54 & & & & molding & malfunction \\
\hline A55 & & & & cover sheet & drop out \\
\hline A56 & & \multirow{8}{*}{$\begin{array}{l}\text { miscellaneous } \\
\text { work }\end{array}$} & \multirow{7}{*}{$\begin{array}{l}\text { kitchen } \\
\text { system }\end{array}$} & & malfunction \\
\hline A57 & & & & & breakage \\
\hline A58 & & & & & fault of attachment \\
\hline A59 & & & & molding & malfunction \\
\hline A60 & & & & door hinge & malfunction \\
\hline A61 & & & & door & opening and closing fault \\
\hline A62 & & & & cover sheet & drop out \\
\hline A63 & & & others & caulking & malfunction \\
\hline
\end{tabular}

\subsection{Defect Occurrence and Repairing Cost Ratio}

The tally of identified defects from the standardized items in Table 2 after surveying total cases is the same as on the left side of Figure 2. In contrast, the tally of repairing costs is on the right side of Figure 2.

In looking at the defect items in terms of the number of cases, it was analyzed as a minimum of 0 cases (A10 and A24), an average of 7.49 cases, and a maximum of 53 cases (A41). Meanwhile, the defect items identified from more than 10 cases among the total 100 cases were 15 types of A41, A27, A7, A52, A61, A35, A17, A25, A43, A34, A56, A50, A55, A30, and A44.

The repair cost ratios for each defect item were a minimum of $0 \%$ (A10 and A24), an average of $1.59 \%$, and a maximum of $24.09 \%$ (A41). In addition, the defect items wherein the repair cost ratio for each item was $1 \%$ or higher were 14 cases of A41, A17, A27, A7, A61, A52, A35, A34, A42, A56, A25, A20, A14, and A8.

A41 (discoloration and breakage in the wooden floor) occurred the most frequently, and the repair cost ratio was also the highest. Therefore, A41 could be considered a critical defect. Similarly, the number of defect occurrences and repair costs was high in A7 (incomplete preservative treatment on the wooden door), A17 (no installation of wooden floor under the kitchen system), and A27 (poor opening and closing of windows). 
Number of defect occurred case (case)

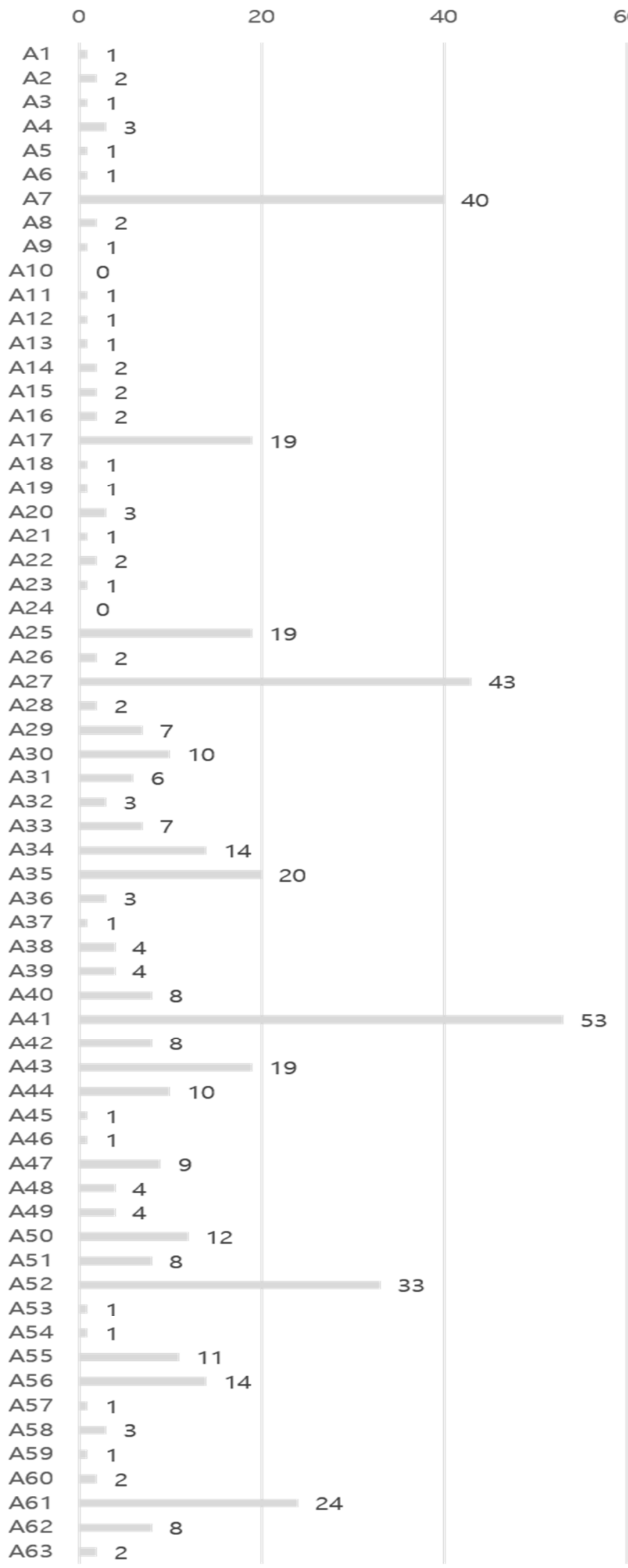

Repairing cost ratio (\%)

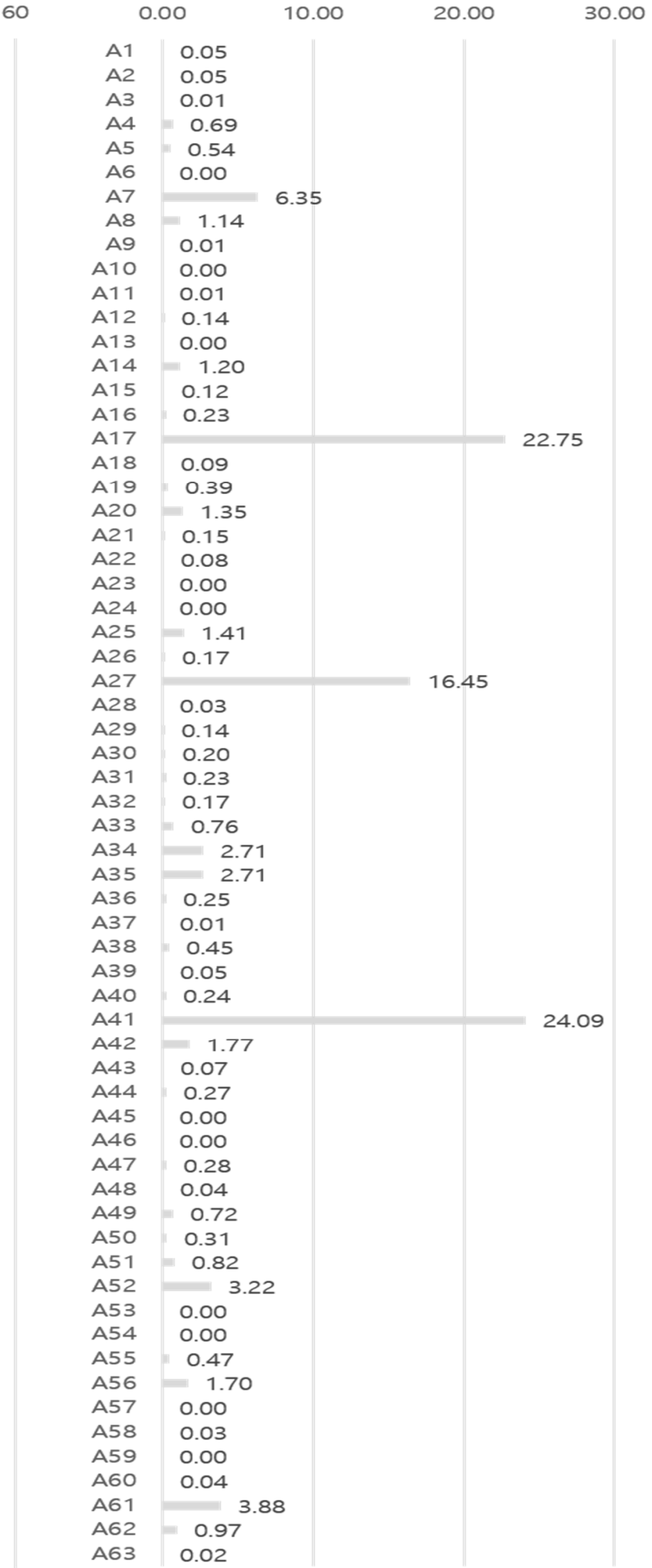

Figure 2. Defect occurrence and repair cost ratio on total defect index. 
Meanwhile, though defect occurrence frequencies were high, repair costs were relatively less in A25 (ceiling molding fault), A34 (warpage of door), A35 (falling of door film), A43 (default in skirting board), A52 (poor opening and closing of the interior furniture), and A61 (poor opening and closing of kitchen system). In addition, since the defect items of A10 and A24 were included in the cases, these were not accepted as defects and were computed as 0 .

Because of the woodwork defect period, that defect occurred before handover was $35.54 \%$, and defect occurred after handover was $64.66 \%$. Therefore, defect-related problems were higher after handover. Furthermore, defects in terms of facility construction occurring in woodwork were $2.38 \%$, in doors and windows $32.57 \%$, finishing works $58.33 \%$, and miscellaneous works $6.71 \%$, which indicates that most of the defects in the woodwork occurred in the finishings and windows.

\subsection{Defect Index A Prime}

Figure 3 shows the comparison of standardized defect items in Figure 2, the $\mathrm{X}$-axis referring to the number of defect occurrence and the Y-axis referring to repairing cost ratio. A brief comparison of each quadrant divided by the average number of defect cases and the average of the defect repair cost ratio in terms of quality and risk management is as follows.

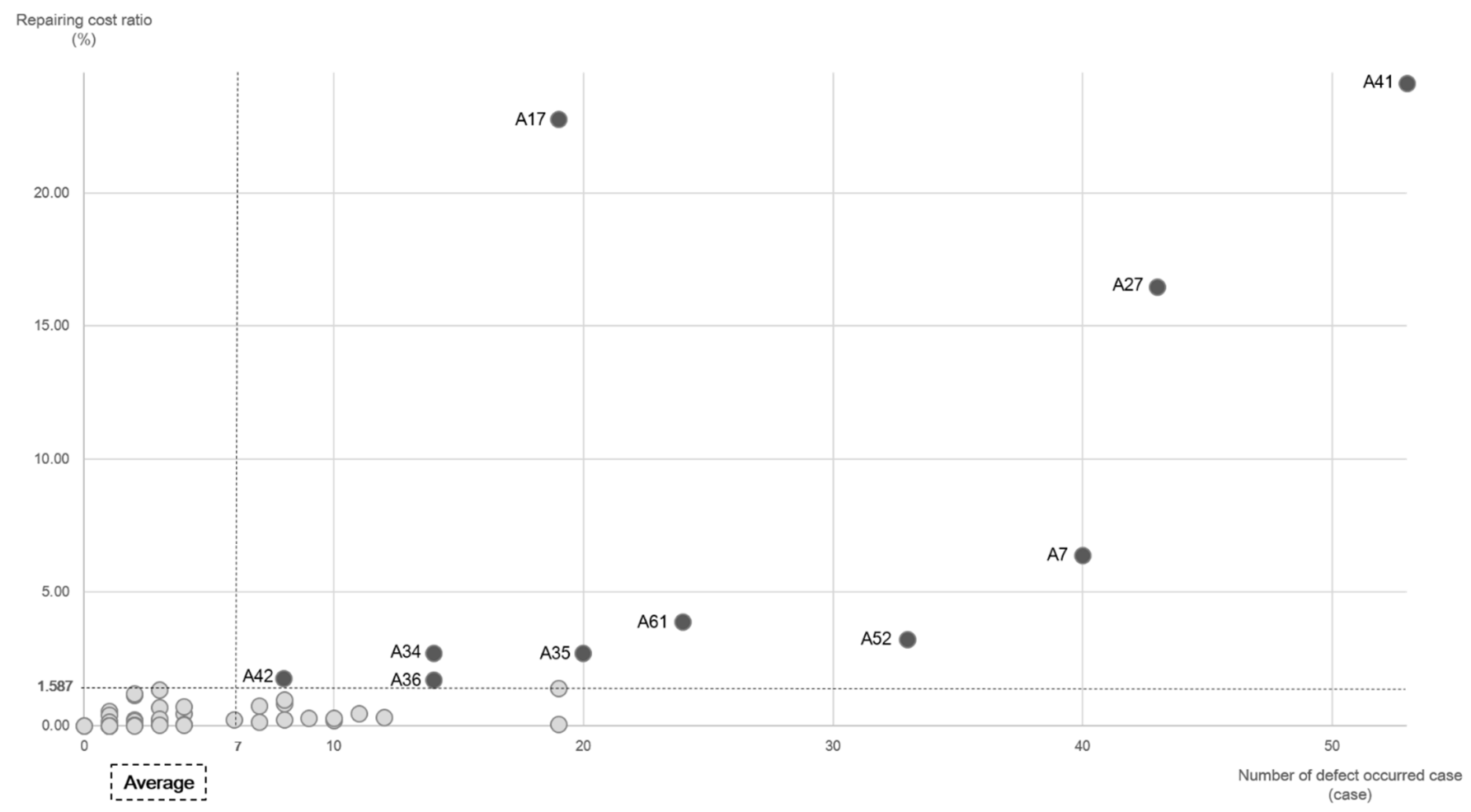

Figure 3. Comparison between defect occurrence and repair cost ratio.

The highest number of cases where both the number of occurring cases and defect repair cost ratio were lower than average was 43 types, including A1, A2, and A3. Since these cases had fewer frequencies of the defect and the damages by defects were not significant, it would not be unreasonable even if day-to-day management is carried out.

There were 10 types of defects where the number of defect occurrences was more than average, but the defect repair cost ratio was below average. In this case, though defect did not occur relatively frequently or in a large number, the damage could be minor. Therefore, monetary damage was less in these cases, but since the frequency was high, the complaint from customers continued.

There was no case observed where the number of defect occurrences was below average, but repair cost was higher than average. In this case, due to an uncertain defect 
that occurred accidentally, the damage was relatively significant. Fortunately, such a defect did not occur in the woodworking.

A total of 10 cases had both a number of defect occurrences and repair costs higher than average, which were A41, A27, A7, A52, A61, A35, A17, A34, A56, and A42. In these cases, since both factors were higher than average, practically defects occurred frequently, and damages were also significant. Therefore, defects that fall under this category can be considered critical. Therefore, such cases were named Index A prime in this study, and this paper proposed them as critical defect items to compare with defect items in the Construction Appraisal Practice and defect judgment standard. Details are discussed in Clause 3.7.

\subsection{Defect Index B}

As discussed in the Introduction, Construction Appraisal Practice designates defect items in the woodworks into six types, which is sub-categorized into eight types as in Table 3. These eight sub-categories of defects were named as Index B to identify with others. The defect items in the Construction Appraisal Practice are similar to those defect types standardized based on the previous cases. For example, category B2 implied the same items as A17, B3 as A15, B4 as A7, and B5 as A27. In addition, B6 was equal to the sum of A50 and A58, B7 was the sum of A52 and A61, and B8 was the sum of A55 and A62. Meanwhile, B1 (mismatch of ceiling frame distance) was not included in the standard defect items.

Table 3. Defect index B.

\begin{tabular}{cccc}
\hline Code & Location & Detailed Object & Phenomena \\
\hline B1 & ceiling & hanger & unmatched frame distance \\
\hline B2 & wooden floor & under kitchen system & non-installation \\
\hline B3 & skirting board & mismatch withdrawing \\
\hline B4 & door & anti-rotting of end pieces & non-installation \\
\hline B5 & window and door & opening and closing fault \\
\hline B6 & interior furniture and kitchen system & fault of attachment \\
\cline { 3 - 3 } B7 & & cover sheet & opening and closing fault \\
\hline B8 & others (no index) & drop out \\
\hline
\end{tabular}

Figure 4 shows the defect repair cost ratio for each defect item in Index B. The defect repair cost was high in the order of B2, B5, B7, B4, B8, B3, and B6. Thus, the repair cost ratio of the defect items presented in the Construction Appraisal Practice was altogether 54.54\% of the total. On the other hand, the repair cost ratio of the defect items not presented in the Construction Appraisal Practice was 45.46\%. 


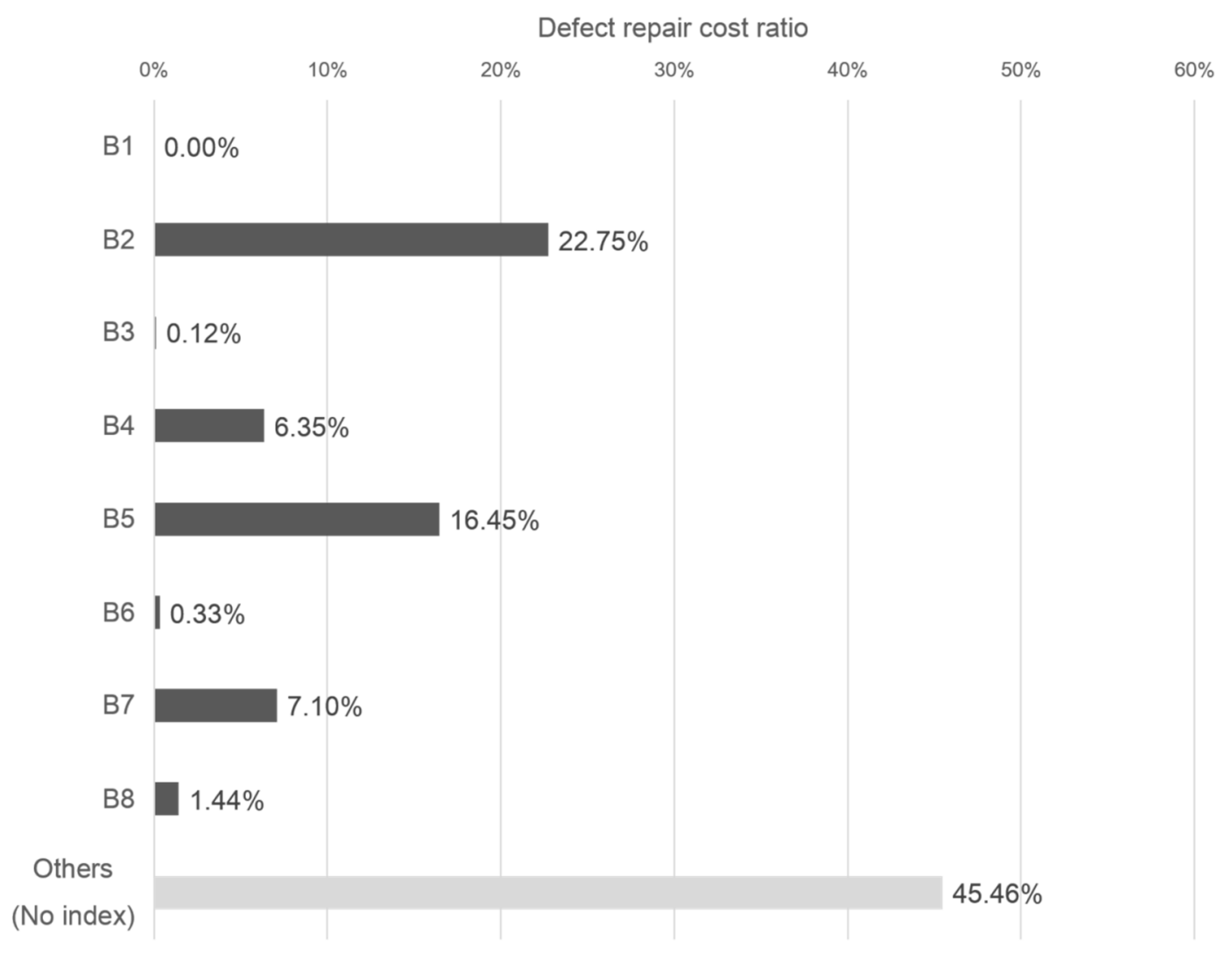

Figure 4. Defect repair cost ratio on index B.

\subsection{Defect Index C}

Table 4 shows the defect items in the woodworks set in the Defect Judgment Standard, and code $C$ was given to present as Index C. Defect items in the defect judgment standard were similar to the defect types in the Construction Appraisal Practice. For example, $\mathrm{C} 1$ was the same as B2 (A17), C2 was B4 (A7), and C3 was B5 (A27).

Table 4. Defect index list on judged standard of defect.

\begin{tabular}{cccc}
\hline Code & Location & Detailed Object & Phenomena \\
\hline C1 & wooden floor & under kitchen system & non-installation \\
\hline C2 & door & anti-rotting of end pieces & non-installation \\
\hline C3 & window and door & & opening and closing fault \\
\hline & others (no index) & & \\
\hline
\end{tabular}

Figure 5 shows the repair cost ratio for each defect item in Index $C$. The repair cost was high in the order of $\mathrm{C} 1, \mathrm{C} 3$, and $\mathrm{C} 2$. For example, the repair cost ratio in the defect items of woodwork listed in the defect judgment standard was $45.54 \%$ of the total, whereas the repair cost ratio for woodworks not presented in the Defect Judgment Standard was 54.46\%. 


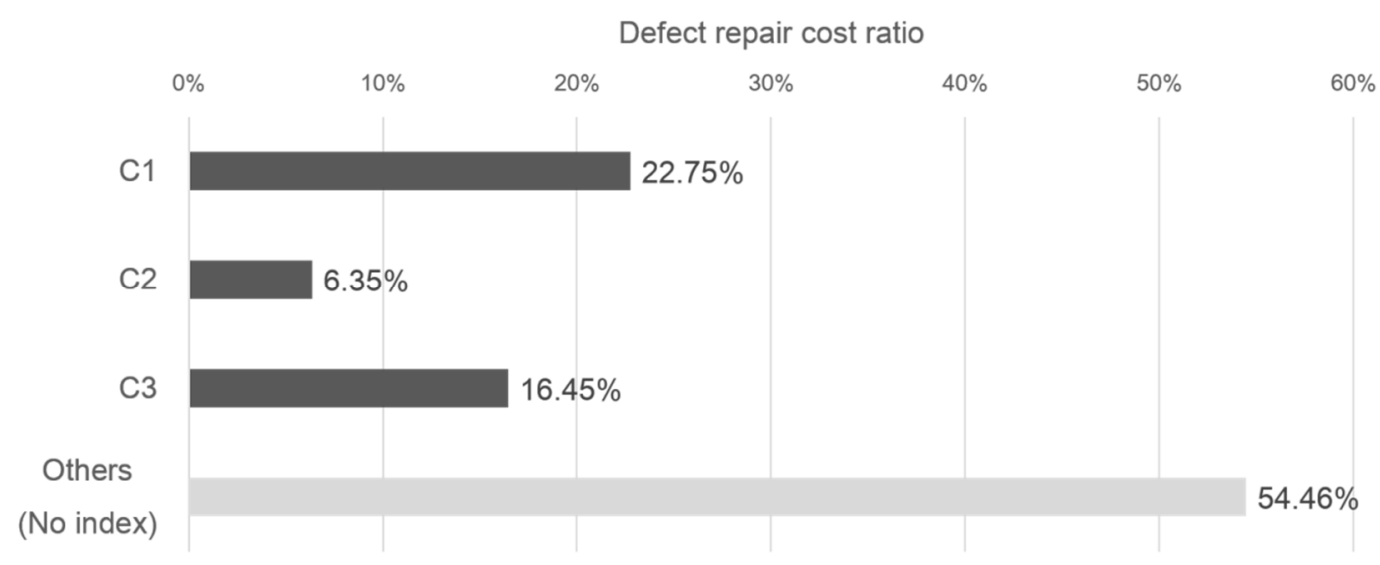

Figure 5. Defect repair cost ratio in defect judgment standard.

\subsection{Comparison of Indices}

As reviewed before, a total of 63 defect items are listed as standardized defect items based on cases for the woodworks. However, it is not reasonable to go for a simple comparison between all 63 items and the two other standards. These standards might have been prepared to focus on the defects that occurred most frequently. Only some of the defects proposed among the defect items in the woodwork might be because these two standards were prepared in 2011 (Construction Appraisal Practice) and 2012 (Defect Judgment Standard) and were at the initial stage of the defect litigation in Korea. Therefore, it would be reasonable to compare by specifying items that are regarded as necessary rather than comparing with all the defective items in the woodwork.

Accordingly, the repair cost ratios of critical defects (10 types), Construction Appraisal Practice (8 types), and Defect Judgement Standard (3 types) were compared with total repair cost as shown in Figure 6. Index B includes $54.54 \%$ of defects, Index C includes $45.54 \%$, and Prime Index includes $85.62 \%$ of defects.

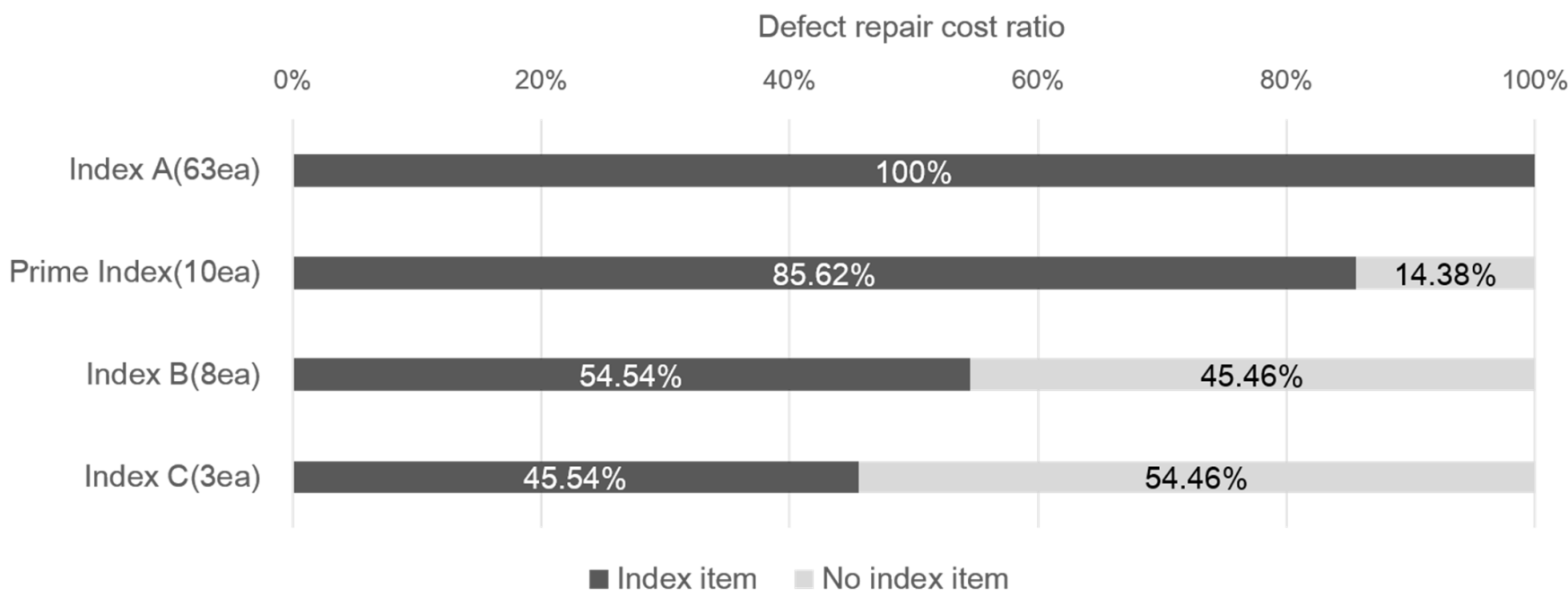

Figure 6. Comparison of defect repair cost ratio by each defect index.

\section{Discussion}

There is no specified standard of method for when, where, and which defects occurred in the woodwork in the house construction and how occurring defects can be categorized. As mentioned above, each preceding study could only cover the defects in some of the products or locations where woods were used, so these have limitations in systemizing defects to the timberworks in the houses [57-59]. Meanwhile, this study has systemized 
defect types related to the timberworks by collecting and analyzing all the defect types associated with the woods in the houses. In addition, the Construction Appraisal Practice and Defect Judgment Standard are defect classification standards for the woodwork defects in Korea's houses. However, research on how precisely the defect classification standard proposed by these two standards represents practically occurring defect data was lacking. Therefore, in this study, a defect classification related to the woodwork that is more appropriate based on the defect occurrence data collected from the houses in Korea is proposed. Accordingly, in this study, defects in the timberwork were standardized as 63 types by utilizing five classification factors of defect occurrence period and facility construction specified in Korean law. In addition, as well as the object, defect location and phenomenon were confirmed through case study. Accordingly, the defects in woodworks were standardized as 63 types by combining defect location and defect phenomena confirmed through defect occurrence times, category of facility works, and case studies outlined in the laws in Korea. The proposed classification is expected to be used as an index to check and confirm the defects in quality control during construction, inspection just before completion, and usage after completion of houses.

Little is known about the frequency of defects in the woodwork in houses and the extent to which damage (repair cost) is incurred due to defects. Furthermore, it is difficult to borrow the base from relevant standards or preceding studies to set standards or factors to designate critical defects. For example, even in the Construction Appraisal Practice and Defect Judgment Standard, it was not disclosed what kinds of bases and indices were adopted to set the defect index [51,53]. In this study, the defect status practically occurring could be figured out through the case study. In addition, the result could be presented as a quantitative index of a number of occurring defect cases and defect repairing cost ratio. However, since each case's magnitude is different, it is difficult to acknowledge only the number of defect cases as an absolute evaluation criterion. Practically, in the case of $\mathrm{A} 43$, it was ranked as 9th with 19 cases, the repair cost was just $0.07 \%$, and the same occurred in the cases of A25 and A50. On the contrary, when repair cost was focused, all the items above the average were included in the critical defects. Therefore, it would be reasonable to combine these two categories to select critical defects. In the preceding studies, it was difficult to establish a policy of quality and risk management since overall defects in the timber works could not be investigated. Meanwhile, if the standard system of defect items and the list of key defects in this study are utilized, these could be efficiently used in establishing quality and risk management related to the timer works.

The repair costs for the critical defect items proposed in this study accounted for $85.62 \%$ of the total repair costs and could explain the defects that practically occurred better than the repair costs of $54.54 \%$ in Construction Appraisal Practice and $45.54 \%$ in the Defect Judgment Standard. Therefore, the critical defects proposed in this study are expected to be used more reasonably than those proposed in the existing standards because of the quality control and risk management of the woodworks. Mainly, because this study proposes a detailed classification system and there is a high level of criticality for each defect type of timber work, it is more advantageous to use it in the quality control of the timberworks than the criteria proposed in the preceding studies. However, one cannot say that the defect items in the Construction Appraisal Practice or Defect Judgment Standard in Korea are unreasonable or useless. It cannot be said whether the defect items in the Construction Appraisal Practice or Defect Judgment Standard are unreasonable or not. In terms of repair cost, it was 54.4\% in the Construction Appraisal Practice, which was more than half, and $45.54 \%$ in the Defect Judgement Standard, which was slightly less than half. B5, B7, B2, C3, $\mathrm{C} 2$, and $\mathrm{C} 1$ in the defect items whose defect repair cost ratio was high corresponded to critical defect items A27, A7, and A17. Thus, these can be utilized in practice. As already mentioned, the Construction Appraisal or Defect Judgment Standard was prepared hastily according to legislation that needed to be used as criteria for defect-related disputes, which is a social issue in Korea. Moreover, other research did not provide much support, and not 
enough discussion between related entities was made. Such institutional imperfection will be supplemented through follow-up efforts such as this study in the future.

Since long-tail theory factors affecting the overall quality and management aspects are many, management and investment are needed for overall factors to solve the problems [73,74]. On the contrary, following Pareto's law, it is a strategy to concentrate on management capability and resource investment if factors affecting the whole items are less [75,76]. Nonetheless, since the Construction Appraisal Practice and Defect Judgment Standard does not fit the long-tail theory or Pareto's law, it is difficult to set a quality control guideline. The number of key defect items selected by the method proposed in this study was 10, occupying $15.87 \%$ of the standard defect items, and the defect repairing ratio reached $85.62 \%$. Therefore, it would be matched to Pareto's law not following Long Tail theory. Therefore, it would be reasonable to go for a select and concentration strategy that conforms to Pareto's law for quality control of the timberwork. Though key defect items in the timberwork tend to follow Pareto's law, Pareto's law did not investigate up to the cause-and-effect relationship between the cause and output, and one can acknowledge such coincidences. Therefore, even if some critical defects in the woodwork in this study follow Pareto's law, if one concludes that it can be equally applied in other cases, it may lead to an error of hasty generalization. Therefore, it needs to be confirmed whether the same trend with this study would be found by securing case data in the future. Also, further research is needed to detect if defect cases other than woodworks also exhibit the same trend or the entire opposite trend.

In the case of defects in housing in Korea, the warranty varies depending on the defect occurrence period, and the subject of responsibility is different [69-71]. Since defect after handover is a subject of warranty by the law, it is possible to claim the cost from both the project owner and the insurer. Since the defect before handover is not a subject of warranty by the law, repair cost cannot be claimed to the insurer but only to the project owner. This means that if a project owner is in default or goes bankrupt, it is possible to receive relief from the insurer for the cost after handover to a certain level, but there is no way to recover for defects before handover. However, defects among the key defects before handover were 2, including A7 and A17, and the repair cost was $29.10 \%$ of the total. Additionally, the number of defect types after handover was 8, including A27 and A34, occupying 56.52\% of the total, which indicated that the weightage of the defect after handover was higher. Therefore, among the key defects in the timberworks, the items which the warranty system could protect were relatively more than those items not protected by the warranty and could be protected better in the repair cost aspect, too. Meanwhile, the defects before handover were judged due to differences in the interpretation of standards such as specification sheets. It is possible to prevent problems in advance to some extent. However, defects after handover and problems gradually appearing while using are relatively difficult to prevent in advance. Nonetheless, the key defects in the timberwork were more after handover, making them difficult to prevent in advance.

The cases of houses collected for this study adopted the standard design following housing design standards in Korea. Thus, the defects in woodwork might be similar, and critical defect items also might be helpful to the criteria. Nevertheless, even if housing in Korea adopts standard design, standard does not mean that specified items are also the same for all. Thus, there could be a difference by specified design level. Suppose one desires to investigate the difference in defect occurrence or repair cost according to the detailed design level, one should know the information about the technology level of material manufacturers and builders according to the design until the construction cost is incurred. However, since construction cost is a trade secret, each enterprise and method could differ in arranging material or workforce input.

Furthermore, data are not abundant considering these points. Therefore, one would have difficulty in judging at present and these points shall be expanded through collecting sufficient relevant data and thorough analysis. Especially for the 10 defect items classified 
as critical defects, in-depth studies should prevent and improve the defect issues, as well as prepare reasonable repair methods.

\section{Conclusions}

In this study, defects occurring in the woodworking were standardized, and selecting critical defects that can be utilized as a management standard was proposed based on 100 defect cases in Korea's housing complexes. The criteria to categorize the standardized defect items in woodworks included defect occurrence time, types of facility construction, location, and object, as well as phenomena that create problems during use. The defect occurrence time was divided into before completion and after completion. Meanwhile, facility construction was categorized into woodworking, window work, finishing work, and miscellaneous work. The defect location and object were categorized as 13 types, and the problematic phenomena included 14 types. Accordingly, a total of 63 types of standardized defects were identified in the woodwork. Ten critical defects were chosen, which were higher than the average level regarding the number of defect occurrences and repair cost. Because the analysis results of the defect data with the key defects suggested in this study can explain well the figure of $85.62 \%$ out of the total defect repair cost, practically occurring defects could be clearer than the defect repair cost of $54.54 \%$ in the Construction Appraisal Practice and $45.54 \%$ in the Defect Judgment Standard.

Author Contributions: The work presented in this article is the result of a collaboration of all authors. J.P. designed the study and wrote the manuscript. D.S. refined the idea and edited the draft. All authors have read and agreed to the published version of the manuscript.

Funding: This work was supported by the National Research Foundation of Korea (NRF) grant funded by the Korean government (2019R1A2C1009913).

Institutional Review Board Statement: Not applicable.

Informed Consent Statement: Not applicable.

Data Availability Statement: The data presented in this study are available on request from the corresponding author.

Conflicts of Interest: The authors declare no conflict of interest.

\section{References}

1. Zeide, B. The science of forestry. J. Sustain. For. 2008, 27, 345-473. [CrossRef]

2. Puletti, N.; Giannetti, F.; Chirici, G.; Canullo, R. Deadwood distribution in European forests. J. Maps 2017, 13, 733-736. [CrossRef]

3. Kim, D.-J. An open-door policy on forests in the 15th 19th centuries Korea, and changes in the forests themselves. YOCKSA WA HYŎNSIL Q. Rev. Korean Hist. 2017, 103, 77-118. [CrossRef]

4. Jin, E.; Chung, Y.-J. Kangwon National University fire risk of wood treated with boron compounds by combustion test. Fire Sci. Eng. 2018, 32, 19-26. [CrossRef]

5. An, D.W. Sustainability and variability of Korean wooden architectural heritage: The relocation and alteration. Sustainability 2018, 10, 1742. [CrossRef]

6. Choi, S.-G.; Choi, Y.-J.; Nam, Y.-J.; Kim, S.-K. Fire Detection tendency through combustion products generated during UL 268 wood flame fire and smoldering fire test. Fire Sci. Eng. 2021, 35, 48-57. [CrossRef]

7. Viholainen, N.; Kylkilahti, E.; Autio, M.; Toppinen, A. A home made of wood: Consumer experiences of wooden building materials. Int. J. Consum. Stud. 2020, 44, 542-551. [CrossRef]

8. Kim, Y.; You, K. The study to environmental factors using microclimate survey of traditional wooden Silsang Temple in Korea. Environ. Monit. Assess. 2018, 190, 630. [CrossRef] [PubMed]

9. Novita, N.; Amiruddin, H.; Ibrahim, H.; Jamil, T.M.; Syaukani, S.; Oguri, E.; Eguchi, K. Investigation of termite attack on cultural heritage buildings: A case study in Aceh Province, Indonesia. Insects 2020, 11, 385. [CrossRef] [PubMed]

10. Son, D.; Lee, D. Evaluation on termite damage of the traditional wooden building by non-destructive methods. J. Korean Wood Sci. Technol. 2008, 36, 21-29.

11. Ferrandez-Villena, M.; Ferrandez-Garcia, C.E.; Garcia-Ortuño, T.; Ferrandez-Garcia, A.; Ferrandez-Garcia, M.T. Analysis of the thermal insulation and fire-resistance capacity of particleboards made from vine (Vitis vinifera L.) prunings. Polymers 2020, 12, 1147. [CrossRef] [PubMed]

12. Okahisa, Y.; Narita, C.; Yoshimura, T. Resistance of wood coated with oriental lacquer (urushi) against damage caused by subterranean termite. J. Wood Sci. 2019, 65. [CrossRef] 
13. Ahmed, S.; Arocho, I. Feasibility assessment of mass timber as a mainstream building material in the US construction industry: Level of involvement, existing challenges, and recommendations. Pract. Period. Struct. Des. Constr. 2021, 26, 04021008. [CrossRef]

14. Chang, Y.; Kim, S.; Son, W.; Lee, S.; Shim, K.; Yeo, H.; Kim, K. Assessment of carbon emission for quantification of environmental load on structural glued laminated timber in Korea. J. Korean Wood Sci. Technol. 2016, 44, 449-456. [CrossRef]

15. Dimitriou, A.; Roberts, P.; Ormondroyd, G. VOC emissions from the combustion of low-grade lignocellulosic waste. Int. Wood Prod. J. 2018, 9, 151-156. [CrossRef]

16. Ryoo, S.; Youn, H. The evolutionary use of curved wood in korean traditional architecture. Sustainability 2019, 11, 6557. [CrossRef]

17. Hong, S. A study on the constructional layout and changes of Chuncheon-Gwana and Chuncheon-Igung. J. Stud. Kangwon Community Cult. 2019, 39, 3-29.

18. Lee, J.; An, D. Selecting the restoration period and source material in the restoration of early Joseon Buddhist temples in Korea. J. Asian Archit. Build. Eng. 2019, 18, 554-574. [CrossRef]

19. Rho, J.; Han, S.; Kim, S.; Choi, J. Cultural memories and imaginary environments projected in landscapes. J. Korean Inst. Tradit. Landsc. Archit. 2017, 15, 15-22.

20. Choi, J. A study on the landscape conservation and management of Dodong Seowon, Unesco World Heritage. J. Korean Inst. Tradit. Landsc. Archit. Int. Ed. 2019, 17, 42-48.

21. Kim, G.; Lee, J. The impact of historic building preservation in urban economics: Focusing on accommodation prices in Jeonju Hanok Village, South Korea. Sustainability 2020, 12, 5005. [CrossRef]

22. McNitta, D.; Alonso, R.; Cherry, M.; Fies, M.; Kellya, M. Influence of forest disturbance on bobcat resource selection in the Central Appalachians. For. Ecol. Manag. 2020, 465, 118066. [CrossRef]

23. Nepomuceno, Í.; Affonso, H.; Fraser, J.; Torres, M. Counter-conducts and the green grab: Forest peoples' resistance to industrial resource extraction in the Saracá-Taquera National Forest, Brazilian Amazonia. Glob. Environ. Chang. 2019, 56, 124-133. [CrossRef]

24. Potter, C.; Kim, J. Austerity in reverse: Korea, capabilities, and crisis. Int. Plan. Stud. 2020, 25, 9-22. [CrossRef]

25. Yoo, M. Ulleungdo situation and Japanese resource exploitation revealed by field survey in Korean empire period. Ocean Policy Res. 2018, 33, 15-57. Available online: https://www.kci.go.kr/kciportal/ci/sereArticleSearch/ciSereArtiView.kci? sereArticleSearchBean.artiId=ART002366772 (accessed on 20 February 2021).

26. Institute for Military History. Statistics on Korean War Damage; Ministry of National Defence: Seoul, Korea, 1996; p. 89. Available online: http:/ / theme.archives.go.kr/viewer/common/archWebViewer.do?bsid=200041027865\&gubun=search (accessed on 20 February 2021).

27. Lee, S. A study on Incheon and the oral history of Korean war. J. Incheon Stud. 2021, 34, 137-185. Available online: http: //www.dbpia.co.kr/journal/articleDetail?nodeId=NODE10532590 (accessed on 20 February 2021). [CrossRef]

28. Grange, A.; Jung, H. The commodification of land and housing: The case of South Korea. Hous. Stud. 2004, 19, 557-580. [CrossRef]

29. Sung, C.; Kim, J.; In, S. Small and medium-sized enterprises policy in Korea from the 1960s to the 2000s and beyond. Small Enterp. Res. 2016, 23, 262-275. [CrossRef]

30. Park, J.; Seo, D. Construction defect and maintenance problem of watering apparatus and sanitary work in apartment building. Int. J. Adv. Sci. Technol. 2020, 29, 949-961. Available online: http://sersc.org/journals/index.php/IJAST/article/view/6553/3972 (accessed on 20 February 2021).

31. Jang-Hwan, J.; So-Hee, P.; JaChoon, K.; Taewoo, R.; Lim, E.M.; Yeo-Chang, Y. Preferences for ecosystem services provided by urban forests in South Korea. For. Sci. Technol. 2020, 16, 86-103. [CrossRef]

32. Lawson, J. Transformation in and challenges to the Korean housing solution. J. Asian Public Policy 2008, 1, 313-327. [CrossRef]

33. Kim, Y.; Choi, M. Why have big construction companies replaced real estate developers in Korea? Int. J. Urban Sci. 2015, 19, 206-223. [CrossRef]

34. Holmans, A. New estimates of housing demand and need in England, 2011 to 2031. Town Ctry. Plan. Tomorrow Ser. 2013, 16, 1-32.

35. Department for Communities and Local Government. Live Tables on House Building-Statistical Data Sets. Available online: http:/ / bit.ly/234uxQc (accessed on 17 October 2020).

36. Zaneldin, E. Investigating the types, causes and severity of claims in construction projects in the UAE. Int. J. Constr. Manag. 2020, 20, 385-401. [CrossRef]

37. Zaneldin, E. Construction claims in United Arab Emirates: Types, causes, and frequency. Int. J. Proj. Manag. 2006, 24, 453-459. [CrossRef]

38. Noble-Allgire, A. Notice and opportunity to repair construction defects: An imperfect response to a perfect storm. Real Prop. Trust Estate Law J. 2009, 43, 729-796.

39. Tazelaar, F.; Snijders, C. Dispute resolution and litigation in the construction industry: Evidence on conflicts and conflict resolution in the Netherlands and Germany. J. Purch. Supply Manag. 2010, 16, 221-229. [CrossRef]

40. UK Commission for Employment and Skills, Sector Skills Insights: Construction, Evidence Report 50, UK Commissions for Employment and Skills. 2012. Available online: https://assets.publishing.service.gov.uk/government/uploads/system/uploads/ attachment_data/file/304475/Sector_Skills_Insights_Construction_evidence_report_50.pdf (accessed on 17 October 2020).

41. Home Builders Federation, the Economic Footprint of UK House Building, Home Builders Federation, 2015. Available online: https://www.hbf.co.uk/documents/6203/Economic_Fotprint_BPF_Report_March_2015_WEB.pdf (accessed on 17 October 2020). 
42. Hopkin, T.; Lu, S.; Rogers, P.; Sexton, M. Detecting defects in the UK New-build housing sector: A learning perspective. Constr. Manag. Econ. 2016, 34, 35-45. [CrossRef]

43. Park, J.; Seo, D. Defect occurrence pattern of wood work in apartment building. Int. J. Adv. Sci. Technol. 2020, $29,942-948$. Available online: https://http://sersc.org/journals/index.php/IJAST/article/view/6553/3971 (accessed on 20 February 2021).

44. Abdou, A.; Haggag, M.; Khatib, O. Use of building defect diagnosis in construction litigation: Case study of a residential building. J. Leg. Aff. Disput. Resolut. Eng. Constr. 2015, 8, C4515007. [CrossRef]

45. Seo, D.; Park, J. Analysis of consulting reports on defect disputes in apartment building. J. Korea Inst. Build. Constr. 2013, 13, 498-505. [CrossRef]

46. Lynda, A.; Bennett, E. Deconstructing the construction defect insurance claim. Environ. Claims J. 2008, 20, 160-180. [CrossRef]

47. Park, J.; Seo, D. Trend of defect occurrence between painting work and finish work in apartment building. Int. J. Recent Technol. Eng. 2019, 8, 927-931. [CrossRef]

48. Iwamatsu, J.; Akiyama, T.; Endo, K. Construction claims and disputes and the business culture of construction in Japan. J. Prof. Issues Eng. Educ. Pract. 2008, 134, 119-127. [CrossRef]

49. National Law Information Center, Enforcement Decree of the Housing Act, South Korea. 2007. Available online: http: / / www.law.go.kr/engLsSc.do?menuId=1\&subMenuId=21\&query=\%EC \%A3\%BC\%ED \%83\%9D \%EB \%B2\%95\%20\%EC\% 8B\%9C\%ED\%96\%89\%EB\%A0\%B9\# (accessed on 20 February 2021).

50. Park, J.; Seo, D. Defect repairing cost and its bond on apartment building in relation to lawsuit parties. Int. J. Innov. Technol. Explor. Eng. 2019, 9, 4882-4887. [CrossRef]

51. Society for Construction Lawsuit in Seoul Central District Court. Construction Appraisal Practice, 3rd ed.; Society for Construction Lawsuit in Seoul Central District Court: Seoul, Korea, 2016. (In Korean)

52. Park, J.; Seo, D.; Um, S.; Kim, C. Defect types of electrical work in house construction. Solid State Technol. 2020, 63, 6428-6443.

53. National Law Information Center, a Judged Standard, Investigated Method and Estimated Costing of Defect in Dwelling House, South Korea. 2016. Available online: http:/ / www.law.go.kr/admRulSc.do?menuId=5\&query=\%ED $\% 95 \% 98 \% E C \% 9 E \% 90 \% E D \%$ $8 \mathrm{C} \% 90 \% \mathrm{EC} \% \mathrm{~A} 0 \% 95 \#$ liBgcolor0 (accessed on 20 February 2021). (In Korean)

54. Kim, B.; Park, J.; Choi, J.; Seo, D.; Kim, O. Comparative analysis on repairing cost of lawsuit on concrete crack defect in apartment building. Korea J. Constr. Eng. Manag. 2011, 12, 142-150.

55. Seo, J. Model for Predicting the Occurrence of Defects in High-Rise Residential Building. Ph.D. Thesis, Korea University, Seoul, Korea, 2009. (In Korean).

56. Seo, D.; Park, J. Comparative analysis on landscape work defect types in apartment buildings through defect dispute case. Asia Life Sci. 2018, 15, 1719-1730.

57. Chong, W.; Low, S. Latent building defects: Causes and design strategies to prevent them. J. Perform. Constr. Facil. 2006, 20, 213-221. [CrossRef]

58. Vásquez-Hernández, A.; Botero, L. Standardizing system of posthandover defects for the construction sector in Colombia. J. Archit. Eng. 2019, 25, 05019004. [CrossRef]

59. Delgado, A.; Brito, J.; Silvestre, J. Inspection and diagnosis system for wood flooring. J. Perform. Constr. Facil. 2013, 27, 564-574. [CrossRef]

60. Mousavi, M.; Taskhiri, M.; Holloway, D.; Olivier, J.; Turner, P. Feature extraction of wood-hole defects using empirical mode decomposition of ultrasonic signals. NDT E Int. 2020, 114, 102282. [CrossRef]

61. Sassu, M.; Falco, A. Legal disputes and building defects: Data from Tuscany. J. Perform. Constr. Facil. 2014, $28,04014017$. [CrossRef]

62. Walsh-Korb, Z.; Avérous, L. Recent developments in the conservation of materials properties of historical wood. Prog. Mater. Sci. 2019, 102, 167-221. [CrossRef]

63. Du, X.; Feng, H.; Hu, M.; Fang, Y.; Chen, S. Three-dimensional stress wave imaging of wood internal defects using TKriging method. Comput. Electron. Agric. 2018, 148, 63-71. [CrossRef]

64. Kamal, K.; Qayyum, R.; Mathavan, S.; Zafar, T. Wood defects classification using laws texture energy measures and supervised learning approach. Adv. Eng. Inform. 2017, 34, 125-135. [CrossRef]

65. Shi, J.; Li, Z.; Zhu, T.; Wang, D.; Ni, C. Defect detection of industry wood veneer based on NAS and multi-channel mask R-CNN. Sensors 2020, 20, 4398. [CrossRef] [PubMed]

66. Korea Ministry of Government Legislation. Enforcement Decree of the Housing Act. Korean Law Information Center. Available online: https: / / www.law.go.kr/lsInfoP.do?lsiSeq=140737\&ancYd=20130531\&ancNo=24569\&efYd=20130531\&nwJoYnInfo= N\&efGubun=Y\&chrClsCd=010202\&ancYnChk=0\#AJAX (accessed on 20 February 2021).

67. Korea Ministry of Government Legislation. Enforcement Decree of the Act on House Contruction Standard. Korean Law Information Center. Available online: https: / / www.law.go.kr/1sSc.do?menuId=1\&subMenuId=15\&tabMenuId=81\&query=

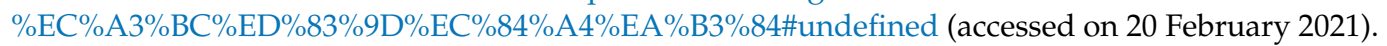

68. Korea Ministry of Government Legislation. Enforcement Regulations of the Act on House Contruction Standard. Korean Law Information Center. Available online: https: / / www.law.go.kr/lsSc.do? menuId=1\&subMenuId=15\&tabMenuId=81\&query= $\%$ EC $\%$ A3\%BC $\%$ ED $\% 83 \% 9 D \% E C \% 84 \% A 4 \% E A \% B 3 \% 84 \#$ undefined (accessed on 20 February 2021). 
69. Korea Ministry of Government Legislation. Housing Act. Korean Law Information Center. Available online: https: / / www.law.go.kr/lsInfoP.do?lsiSeq=140971\&ancYd=20130604\&ancNo=11871\&efYd=20130604\&nwJoYnInfo=N\&efGubun= Y\&chrClsCd=010202\&ancYnChk=0\#0000 (accessed on 20 February 2021).

70. Korea Ministry of Government Legislation. Enforcement Decree of the Act on the Ownership and Management of Aggregate Buildings. Korean Law Information Center. Available online: https://www.law.go.kr/1sInfoP.do?lsiSeq=141246\&ancYd= $20130617 \& a n c N o=24605 \&$ ef $Y d=20130619 \& n w J o Y n I n f o=N \& e f G u b u n=Y \& c h r C l s C d=010202 \& a n c Y n C h k=0 \# 0000$ (accessed on 20 February 2021).

71. Korea Ministry of Government Legislation. Civil Act. Korean Law Information Center. Available online: https: / / www.law.go.kr/lsSc.do?menuId=1\&subMenuId=15\&tabMenuId=81\&query= $\%$ ED $\% 91 \% 9 \mathrm{C} \% \mathrm{EC} \% \mathrm{~A} 4 \% 80 \% \mathrm{EC} \% 84 \% \mathrm{~A} 4$ \%EA\%B3\%84\#undefined (accessed on 20 February 2021).

72. Choi, J.; Park, J.; Seo, D.; Jo, J.; Park, K.; Kim, O. A Study on legal issues about defect repair claim on apartment building. J. Archit. Inst. Korea 2019, 25, 145-153.

73. Brynjolfsson, E.; Hu, Y.; Simester, D. Goodbye pareto principle, hello long tail: The effect of search costs on the concentration of product sales. Manag. Sci. 2011, 57, 1373-1386. [CrossRef]

74. Hinz, O.; Eckert, J.; Skiera, B. Drivers of the long tail phenomenon: An empirical analysis. J. Manag. Inf. Syst. 2011, 27, 43-69. [CrossRef]

75. Chen, Y.; Chong, P.; Tong, M. Mathematical and computer modelling of the pareto principle. Math. Comput. Model. 1994, 19, 61-80. [CrossRef]

76. Lopez, F.; Bartolo, C.; Piazza, T.; Passannanti, A.; Gerlach, J.; Gridelli, B.; Triolo, F. A quality risk management model approach for cell therapy manufacturing. Risk Anal. 2010, 30. [CrossRef]

77. Bank of Korea. Economics Statistics System. Available online: http:/ / ecos.bok.or.kr (accessed on 20 June 2021). 